\title{
Progeny testing of Pinus sylvestris L. of seed orchard in different environmental conditions
}

\author{
Olga Mazhula ${ }^{1}$, Yaroslav Fuchylo ${ }^{1}$, Yuriy Hayda ${ }^{2}$, Mykola Kharytonov $^{3, *}$, Svitlana Matkovska ${ }^{4}$ \\ ${ }^{1}$ Institute of Bioenergy Crops and Sugar Beet of NAAS, Kyiv, Klinichna St 25, 03141,Ukraine \\ ${ }^{2}$ Western Ukrainian National University, Ternopil, Lvivska St 11, 46020, Ukraine \\ ${ }^{3}$ Dnipro State Agrarian and Economic University, Dnipro, Sergey Efremov St 25, 49600, Ukraine, \\ ${ }^{4}$ Zhytomyr National Agroecological University, Zhytomyr, Staryi Boulevard 7, 10008, Ukraine \\ *corresponding author e-mail: kharytonov.m.m@dsau.dp.ua
}

Received: 21 December 2020 / Accepted: 29 September 2021

\begin{abstract}
Evaluation of the progeny test of plus trees of Scots pine - a necessary condition for determining the prospects the use of improved seeds in different environmental conditions. The paper presents the results of the study of the progeny test of groups of clones of plus trees of Scots pine selected according to certain characteristics in Northern Steppe and South Forest-Steppe of Ukraine. Analysis of results showed: a significant improvement in the growth rates of the all testing progenies of seed orchard in the better climatic and soil conditions of South Forest-Steppe between the ages of 3 and 10 years. At the same time, 4 out of 5 studied progenies worsened their growth indicators relative to local control at the age of 3 to 26 years in less optimal climatic and soil conditions of Northern Steppe. The leader in the steppe conditions was the progeny of a fraction of three clones, which had the highest seed productivity. The selection of the fastest growing clones and the rejection of the slowest growing ones had a positive effect on the growth of progenies of seed orchards at both test points.
\end{abstract}

Keywords: Scots pine, plus-trees, rates, clone, test, seed orchards.

\section{Introduction}

Scots pine (Pinus sylvestris L.) is the most extensively grown and economically important species in Ukraine. Genetic improvement of this species began from the 60 s of the last century, when the first phenotypically superior plus-trees were selected from natural environments. The breeding activities covered establishing a first generation of seedling and clonal seed orchards in different regions of the country. Total area of first-generation seed orchards of Scots pine was about 600 hectares. These seed orchards were established using the nontested plus trees. Clones of seed orchards were involved in progeny tests since 80-90 years (Hayda et al., 2019).

Assessment of plus trees of coniferous species by the growth of their seed progenies in different ecological environmental is carried out in many countries around the world (Danusevicius \& Lindgren, 2004; Stoehr et al., 2004;
Kroon et al., 2007; Kurm et al., 2009; Berlin et al., 2015; Ivković et al., 2015; Lai et al., 2017). Breeding values of plus trees were estimated by the research of individual plus trees progenies (Lee, 2002) and by the common garden experiment testing of seed orchards (Chmura et al., 2012). According to scientists, plantations of genetically improved forest trees are critical for economic sustainability in forestry (Jansson et al., 2016). Tree breeding can increase volume growth in the range 10-25\%, and use value associated with genetically improved trees gives a better return on investment and a shorter rotation period.

The creation and subsequent evaluation of progeny tests of plus trees requires a significant amount of time and funding. That is why we used the evaluation of clones in seed orchards on the economic characteristics to speed up this process. This assessment will significantly compensate for the mistakes that were made in the selection of plus trees, as seed orchards are characterized by a balanced agro background 
and each plus tree is represented by a large number of vegetative progenies (genetically identical to the parent tree), evenly distributed over the area. The main objective of this paper was to investigate whether it is possible to achieve more intensive growth of Scots pine stands using the seeds of a certain group of clones or a certain special proportion of seeds of different clones. We tried to identify whether the seed productivity of clones of plus trees affects the growth of their progenies in different ecological conditions and to evaluate the effectiveness of the selection of the fastest growing clones of plus trees and the rejection of the slowest growing ones.

\section{Materials and methods}

The researches were conducted in the left-bank part of Ukraine, in Northern Steppe (State Forest Enterprise "Izyumske") and South Forest-Steppe (State Forest Enterprise “Zmiivske”) (Table 1).

Table 1. The mean meteorological data Ukraine's Northern Steppe and South Forest-steppe (Izyum and Slobozhanska weather stations Kharkiv region)

\begin{tabular}{|c|c|c|c|c|c|c|c|c|}
\hline \multirow[b]{3}{*}{ Months } & \multicolumn{6}{|c|}{ Temperature ${ }^{\circ} \mathrm{C}$} & \multirow{2}{*}{\multicolumn{2}{|c|}{$\begin{array}{c}\text { Precipitation } \\
\mathrm{mm}\end{array}$}} \\
\hline & \multicolumn{2}{|c|}{ mean } & \multicolumn{2}{|c|}{ maximum } & \multicolumn{2}{|c|}{ minimum } & & \\
\hline & $\begin{array}{l}\frac{\tilde{a}}{2} \\
\frac{\tilde{\nu}}{\omega}\end{array}$ & 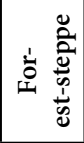 & 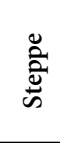 & 菅 & 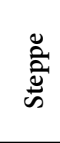 & 竞竞 & 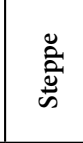 & 苛竞 \\
\hline January & -4.1 & -4.2 & 13 & 11 & -40 & -30 & 48 & 44 \\
\hline February & -4.0 & -4.2 & 16 & 15 & -36 & -30 & 43 & 41 \\
\hline March & 1.3 & 1.1 & 24 & 23 & -35 & -34 & 44 & 40 \\
\hline April & 9.5 & 9.4 & 31 & 30 & -8 & -7 & 38 & 36 \\
\hline May & 15.6 & 15.7 & 33 & 33 & -2 & 0 & 48 & 53 \\
\hline June & 19.5 & 19.4 & 38 & 36 & 3 & 3 & 63 & 68 \\
\hline July & 21.5 & 21.3 & 39 & 37 & 7 & 6 & 59 & 68 \\
\hline August & 20.1 & 20.2 & 39 & 39 & -1 & 2 & 38 & 38 \\
\hline September & 14.4 & 14.4 & 34 & 32 & -6 & -3 & 49 & 52 \\
\hline October & 8.0 & 8.1 & 31 & 25 & -20 & -10 & 43 & 44 \\
\hline November & 2.0 & 1.7 & 22 & 18 & -24 & -22 & 48 & 45 \\
\hline December & -2.9 & -3.1 & 14 & 14 & -32 & -28 & 46 & 43 \\
\hline
\end{tabular}

The locations are most different in minimum temperatures, less in maximum temperatures and precipitation. The minimum temperature of the coldest month (January) is $-40^{\circ} \mathrm{C}$ in Steppe and $-30^{\circ} \mathrm{C}$ in Forest-Steppe. The maximum temperature of the warmest month (July) is $+39^{\circ} \mathrm{C}$ in Steppe and $+37^{\circ} \mathrm{C}$ in Forest-Steppe. The mean annual precipitation is $567 \mathrm{~mm}$ in Steppe and $572 \mathrm{~mm}$ in Forest-Steppe. Soil conditions on first plot (Steppe) are characterized as very poor sandy dry and fresh soils: $A_{1-2}$, in accordance with edaphical scale by Alekseev-Pogrebnyak; on second plot (Forest-Steppe) - poor fresh sandy loam soil: $B_{2}$ (Pogrebnyak, 1955). Progeny tests of Scots pine seed orchard were created by one of the authors of the article in 1993 and regular measurements were carried out from 1996 to 2019. The seeds for these progeny tests were collected on clonal seed orchard created 1972 in the State Forest Enterprise "Zmiivske". There are 19 clones of plus trees of Scots pine of the 3 forest enterprises ("Zmiiv" - Z-1-6, 8-11, Zd-12, 22-25; "Guty" - G-7; “Zhovtneve" - M-14, 15, 28) from Kharkiv region in this seed orchard. Number of ramets per clone varied between 11 and 25 . These plus trees were selected in the forest-steppe part of Kharkiv region, as no such trees were found in the steppe part. The investigation of yield of cones and growth of clones was conducted for 8 years on seed orchard (Mazhula \& Voityuk, 2000). The seedlings have been grown under the same conditions in the greenhouse. The half sib progenies from free pollination of clones of plus trees have been tested in both plots (in Steppe and in Forest- Steppe zone). Progeny tests of each seed lot were placed randomized in $2 \mathrm{x}$ replications (total 100 seedlings on one plot from each seed lot). Five seed lots (seed mixtures) were formed according to the following schemes (Table 2).

Table 2. Structure of Pinus sylvestris seed lots

\begin{tabular}{|c|l|l|}
\hline $\begin{array}{c}\text { Seed } \\
\text { lot }\end{array}$ & The method of seed lot formation & \multicolumn{1}{|c|}{ Clones of seed lot } \\
\hline I & $\begin{array}{l}\text { seeds from all clones in the same } \\
\text { percentage }\end{array}$ & $\begin{array}{l}\mathrm{Z}-1-6,8-11, \mathrm{Zd}-12, \\
22-25 ; \mathrm{G}-7 ; \mathrm{M}-14,15,28\end{array}$ \\
\hline II & $\begin{array}{l}\text { seeds from all clones proportionally } \\
\text { to its seed productivity }\end{array}$ & $\begin{array}{l}\mathrm{Z}-1-6,8-11, \mathrm{Zd}-12, \\
22-25 ; \mathrm{G}-7 ; \mathrm{M}-14,15,28\end{array}$ \\
\hline III & $\begin{array}{l}\text { seeds of the three fastest growing } \\
\text { clones in the same proportion }\end{array}$ & $\mathrm{Z}-5,10, \mathrm{Zd}-23$ \\
\hline IV & $\begin{array}{l}\text { seeds of the three most slowly grow- } \\
\text { ing clones in the same proportion; }\end{array}$ & $\mathrm{M}-28, \mathrm{Z}-11, \mathrm{Zd}-12$ \\
\hline V & $\begin{array}{l}\text { seeds of three clones with the } \\
\text { highest seed yield in the same } \\
\text { proportion. }\end{array}$ & Z-3, 10, Zd-24 \\
\hline
\end{tabular}

Seedlings for control in Forest-Steppe have been grown from the total collection of seeds in Forest Enterprise "Zmiivske" (about 500 ha) and for control in Steppe in Forest Enterprise "Izyumske" (about 400 ha). One local control on the Forest-Steppe plot (200 seedlings) and two controls on the Steppe plot (one from Forest-Steppe and other from Steppe or 350 and 200 seedlings) were planted. Simultaneous study of both progeny tests was conducted in 1996 at 3 year of age: mean height and average increment were measured for all trees. Next measurements were carried out at age 10 in the Forest-Steppe and 12 years - in the Steppe zone. The following parameters were determined: height and quadratic breast height diameter (DBH) and stem volume. First plot (in Forest-steppe zone) was designed in a way which allows the later use as seedling seed orchard. Trees were gradually 
removed as closing the treetops, which affected their number in the studied progeny, and it lost its value as a progeny test since age 11 in this plot. In the second plot (in Steppe), last studies were conducted at 26 years of age. The significance of the difference between progenies of seed lots and controls was estimated by the Student's t-test. The stem volume of growing pine trees was calculated by the formula (Anuchin, 1982):

$$
V=d^{2} \cdot x \cdot(0.31 \cdot x \cdot h+1.0) \cdot x \cdot 10^{-4}
$$

where: $V$ - stem volume, $\mathrm{m}^{3} ; d-\mathrm{DBH}-$ mean quadratic breast height diameter, $\mathrm{cm} ; h$ - mean height, $\mathrm{m}$.

Two-way ANOVA analysis of variance was run on data of biometrical parameters of progenies of selection mixtures at ages 10 in the Forest-Steppe and 12 in the Steppe zones. To be able to compare the growth rates of progenies in different areas, their value in the Steppe at 10 years of age was calculated. For this purpose, the average increments in heights and diameters for 12 years were calculated for each progeny in the Steppe zone. Growth indicators at the age of 12 were reduced by two year increments. The Fisher's LSD test was used for multiple pair wise comparisons of the growth rates of the seed lot progenies. The Bonferroni test was applied to compare the average traits across the test sites. The following model was applied:

$$
Y_{i j k}=\mu+F_{i}+B_{j}+F B_{i j}+\varepsilon_{i j k}
$$

where: $Y_{i j k}$ - is the value of $k$ - th individual of $i$-th progeny of seed lot in $j$ - th - site; $\mu$ - is the overall mean; $F_{i}$ - is the random effect of seed lot $(=1, \ldots 6) ; B_{j}$ - is the fixed effect of $J$-th plot $(j=2), F B_{i j}$ - is the effect of interaction between $i$ - th seed lot and $j$ - th site; $\varepsilon_{i j k}-$ is the residual error.

\section{Results and discussion}

The results of measurements of progeny tests at the 3 years age (Table 3) showed that in Ukraine's Northern Steppe the progenies of almost all seed lots grew significantly better than local control. Offsprings of all five seed lots were significantly better than control in height $(t=3.05-7.77)$. Four seed mixtures (I, II, III, V) were significantly better in annual increment in height too $\left(\mathrm{t}=2.73-5.45, \mathrm{t}_{0.05}=1.98\right)$. Progeny of seed lot IV (from seeds of the slowest growing clones) grew significantly better only in height. Survival of Scots Pine progenies in Steppe was high enough and varied from 74 to $89 \%$. This indicator in the Forest-Steppe was lower and varied from 38 to $50 \%$. Biometrical parameters of seed lot progeny in Ukraine's South Forest-Steppe were higher than in Northern Steppe Meantime all seed lot offspring. in this site grew worse than control.
Table 3. Survival, height $(\mathrm{H}, \mathrm{m})$ and height increment $(\mathrm{Z}, \mathrm{cm})$ of

\begin{tabular}{|c|c|c|c|c|c|c|}
\hline \multirow{2}{*}{$\begin{array}{c}\text { Seed } \\
\text { lot }\end{array}$} & \multirow[b]{2}{*}{ Site } & \multirow{2}{*}{$\begin{array}{c}\text { Sur- } \\
\text { vival, } \\
\%\end{array}$} & \multicolumn{2}{|c|}{$\mathrm{H}$} & \multicolumn{2}{|c|}{$\mathrm{Z}$} \\
\hline & & & $\overline{\mathrm{X}} \pm \mathrm{S}_{\overline{\mathrm{X}}}$ & $t$ & $\overline{\mathrm{X}} \pm \mathrm{S}_{\overline{\mathrm{X}}}$ & $\mathrm{t}$ \\
\hline \multirow[t]{2}{*}{ I } & $S$ & 82 & $0.92 \pm 0.03$ & $6.10^{\star * *}$ & $36.8 \pm 1.7$ & $4.69^{\star * *}$ \\
\hline & FS & 50 & $0.94 \pm 0.05$ & -1.86 & $38.8 \pm 1.9$ & -1.52 \\
\hline \multirow[t]{2}{*}{ II } & $S$ & 77 & $0.91 \pm 0.04$ & $4.70^{\star * \star}$ & $33.2 \pm 1.4$ & $2.73^{\star \star}$ \\
\hline & FS & 47 & $0.91 \pm 0.06$ & $-2.06^{*}$ & $38.3 \pm 1.8$ & -1.80 \\
\hline \multirow[t]{2}{*}{ III } & $\mathrm{S}$ & 89 & $0.93 \pm 0.03$ & $6.38^{\star * *}$ & $36.0 \pm 1.4$ & $4.46^{* * *}$ \\
\hline & FS & 55 & $0.97 \pm 0.05$ & -1.30 & $40.4 \pm 1.7$ & -0.87 \\
\hline \multirow[t]{2}{*}{ IV } & $S$ & 86 & $0.81 \pm 0.03$ & $3.05^{\star *}$ & $30.9 \pm 1.2$ & 1.88 \\
\hline & FS & 43 & $1.01 \pm 0.06$ & -0.47 & $41.1 \pm 1.7$ & -0.53 \\
\hline \multirow[t]{2}{*}{ V } & $S$ & 74 & $0.98 \pm 0.03$ & $7.77^{* * *}$ & $37.2 \pm 1.4$ & $5.45^{\star * *}$ \\
\hline & FS & 38 & $1.02 \pm 0.03$ & -0.55 & $39.8 \pm 1.8$ & -1.11 \\
\hline \multirow{2}{*}{$\begin{array}{l}\text { Con- } \\
\text { trol }\end{array}$} & $\mathrm{S}$ & 75 & $0.70 \pm 0.02$ & - & $27.2 \pm 1.5$ & - \\
\hline & FS & 65 & $1.04 \pm 0.02$ & - & $42.2 \pm 1,2$ & - \\
\hline
\end{tabular}
3 years old progenies of Pinus sylvestris seed lots

$\mathrm{t}$-value relative to control, the value at a significance level of ${ }^{\star} 0.05 ;{ }^{* \star} 0.01 ;{ }^{* * *} 0.001$

Although it should be noted that statistically these lags from control were insignificant. Student's t-statistic for height was from -0.47 to -1.86 by $t_{0.05}=1.98$. There was only one significantly worse result in height than local control among the studied mixtures (seed lot II, which was formed from seeds of each 19 clones proportionally to its seed productivity). The progeny of seed lot $\mathrm{V}$, which formed from seed of three clones with the highest seed yield in the same proportion, was better at 3 year age among all variants both in Steppe and in Forest-Steppe. The progenies survival in the Steppe decreased significantly up to $22-41 \%$ after 9 years (Table 4).

It was especially characteristic of the offspring of the IV seed lot. In more favorable conditions for the growth of Scots Pine in the Forest Steppe zone, the survival of seed mixtures after 7 years also decreased by a significant amount (22-36\%).

Frequent droughts and intense damage of Diprion pini pines significantly reduced the survival of the progeny test. All five seed lot progenies were significantly higher than control both in Steppe (at 12 years age) and Forest-Steppe zone (at 10 years age) $(\mathrm{t}=2.12-5.53)$. Stem diameter of all progenies in Steppe zone was also greater $(t=2.19-5.41$ by $\left.\mathrm{t}_{0.05}=1.98\right)$. In Forest-Steppe zone only variants II and III (seeds from the three fastest growing clones in the same proportion) were significantly better than control in $\mathrm{DBH}$ $\left(\mathrm{t}=2.20\right.$ and 3.13 by $\left.\mathrm{t}_{0.05}=2.03\right)$. $\mathrm{DBH}$ of other progenies ( $\mathrm{I}$, IV and V) statistically did not differ from control in this site. The stem volume of the control and selected material was estimated at the age of 10 years and 12 years. All five seed lot progenies had more volume than the control both in Steppe (up to 45-123\%) and Forest-Steppe zone (up to 3-54\%). The progeny of fast-growing clones (III fractions) showed one 
Table 4. Survival, height $(\mathrm{H}, \mathrm{m})$, breast height diameter of stem $(\mathrm{DBH}, \mathrm{cm})$ and stem volume $\left(\mathrm{V}, \mathrm{m}^{3}\right)$ of 10 (in Forest-Steppe) and 12 (in Steppe) years old progenies of Pinus sylvestris seed lots

\begin{tabular}{|c|c|c|c|c|c|c|c|c|}
\hline \multirow{2}{*}{ Seed lot } & \multirow{2}{*}{ Site } & \multirow{2}{*}{ Survival, \% } & \multicolumn{2}{|c|}{$\mathrm{H}$} & \multicolumn{2}{|c|}{ DBH } & \multicolumn{2}{|c|}{ V } \\
\hline & & & $\overline{\mathrm{X}} \pm \mathrm{S}_{\overline{\mathrm{X}}}$ & $\mathrm{t}$ & $\overline{\mathrm{X}} \pm \mathrm{S}_{\overline{\mathrm{X}}}$ & $\mathrm{t}$ & $\mathrm{m}^{3}$ & $\%$ to control \\
\hline \multirow[t]{2}{*}{ I } & $\mathrm{S}$ & 50 & $4.87 \pm 0.17$ & $3.81^{* * *}$ & $5.3 \pm 0.3$ & $2.99^{* *}$ & 0,0071 & 170 \\
\hline & FS & 14 & $5.62 \pm 0.07$ & $3.03^{\star *}$ & $12.2 \pm 0.5$ & 1.17 & 0.041 & 118 \\
\hline \multirow[t]{2}{*}{ II } & $S$ & 55 & $4.53 \pm 0.13$ & $2.62^{* *}$ & $5.0 \pm 0.3$ & $2.19^{*}$ & 0,0061 & 145 \\
\hline & FS & 14 & $5.62 \pm 0.16$ & $2.12^{*}$ & $13.4 \pm 0.8$ & $2.20^{*}$ & 0.049 & 142 \\
\hline \multirow[t]{2}{*}{ III } & S & 51 & $5.05 \pm 0.12$ & $5.53^{\star * *}$ & $5.6 \pm 0.2$ & $4.17^{\star * *}$ & 0,0079 & 188 \\
\hline & FS & 14 & $5.59 \pm 0.14$ & $2.17^{\star}$ & $14.0 \pm 0.7$ & $3.13^{* *}$ & 0.054 & 154 \\
\hline \multirow[t]{2}{*}{ IV } & $S$ & 45 & $4.72 \pm 0.18$ & $3.03^{\star *}$ & $5.4 \pm 0.3$ & $2.64^{\star *}$ & 0,0071 & 170 \\
\hline & FS & 16 & $5.65 \pm 0.13$ & $2.71^{\star *}$ & $11.4 \pm 0.8$ & -0.11 & 0.036 & 103 \\
\hline \multirow[t]{2}{*}{$\mathrm{V}$} & S & 41 & $4.82 \pm 0.11$ & $5.28^{\star * *}$ & $5.8 \pm 0.2$ & $5.41^{\star * *}$ & 0,0094 & 223 \\
\hline & FS & 16 & $5.54 \pm 0.11$ & $2.22^{\star}$ & $12.6 \pm 0.6$ & 1.73 & 0.043 & 124 \\
\hline \multirow[t]{2}{*}{ Control } & $S$ & 45 & $4.03 \pm 0.14$ & - & $4.3 \pm 0.2$ & - & 0,0042 & 100 \\
\hline & FS & 23 & $5.25 \pm 0.07$ & - & $11.5 \pm 0.3$ & - & 0.035 & 100 \\
\hline
\end{tabular}

$\mathrm{t}$-value relative to control, the value at a significance level of ${ }^{\star} 0.05 ;{ }^{* *} 0.01 ; * * * 0.001$

of the best results: exceeding was respectively 88 and $54 \%$ on both sites. Progeny of seed lot V was also characterized by great stem volume (especially in Steppe zone). Trees of variants I and II were characterized by large stem volume in the conditions of the Steppe zone and smaller in the conditions of the Forest Steppe zone.

Two-factor dispersion analysis (main effects ANOVA from STATISTICA statistical software package) has been applied to evaluate the influence of two qualitative variables (factors), such as test site and seed lot type on progenies growth. ANOVA test showed that the growing conditions (factor Site) had significant effect $(\mathrm{p}<0.001)$ on the variation of progenies height (Table 5).

Table 5. Results of two-way ANOVA analysis of variance of the seed lot progenies height at the age 10 years

\begin{tabular}{|l|r|r|r|r|c|}
\hline \multicolumn{1}{|c|}{ Effect } & \multicolumn{1}{c|}{ SS } & \multicolumn{1}{c|}{ DF } & \multicolumn{1}{c|}{ MS } & \multicolumn{1}{c|}{ F } & \multicolumn{1}{c|}{ p } \\
\hline Intercept & 6777.820 & 1 & 6777.820 & 11280.64 & $<0.001$ \\
\hline Site & 181.365 & 1 & 181.365 & 301.85 & $<0.001$ \\
\hline Seed lot & 4.228 & 5 & 0.846 & 1.41 & 0.220 \\
\hline Site / Seed lot & 3.834 & 5 & 0.767 & 1.28 & 0.273 \\
\hline Error & 334.666 & 557 & 0.601 & & \\
\hline
\end{tabular}

At the same time, the impact of other factor (Seed lot) was not significant $(\mathrm{p}=0.220>0.05)$. The interaction between these two factors turned out to be also not significant $(\mathrm{p}=$ $0.273>0.05)$.

Thus, ANOVA results show that the ecological conditions of the Steppe and Forest-Steppe zones have a much greater effect on height of the tested progenies than their genetic characteristics. However, based on graph data of the average height of different progenies in both sites (Fig. 1), one can note that 4 out of 5 progenies of the seed orchards exceed the height of control (for Forest-Steppe zone).

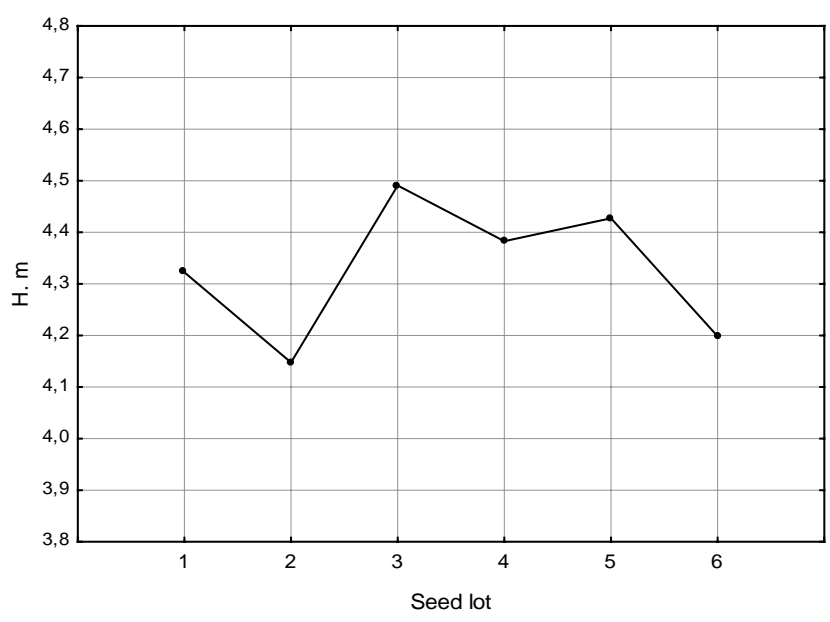

Figure 1. Mean height of the seed lot progenies on both test sites at the age 10 years (6-control for Forest-Steppe zone)

The better results in height grow were shown by the progeny of the fastest growing clones (III seed lot). The significance of the difference in height of the tested progenies was determined using Fisher's LSD method for multiple pair wise comparisons (Table 6).

Fisher's LSD test revealed that two seed lot progenies (III, $\mathrm{p}=0.007$ and $\mathrm{V}, \mathrm{p}=0.047$ ) were significant higher than Forest-Steppe control. These two progenies are significantly higher than the progeny of the fraction II too ( $\mathrm{p}=0.011$ and 0.045).

Meantime, ANOVA test of progenies DBH variation showed that both factors (Site and Seed lot) and their 
Table 6. Results of pair wise comparisons of the average height of the seed lot progenies (LSD test)

\begin{tabular}{|c|c|c|c|c|c|c|}
\hline $\begin{array}{c}\text { Seed } \\
\text { lot }\end{array}$ & I & II & III & IV & V & $\begin{array}{c}\text { control } \\
\text { F-steppe }\end{array}$ \\
\hline I & 1,000 & 0.183 & 0.209 & 0.656 & 0.450 & 0.235 \\
\hline II & 0.183 & 1,000 & $\mathbf{0 . 0 1 1}$ & 0.085 & $\mathbf{0 . 0 4 5}$ & 0.631 \\
\hline III & 0.209 & $\mathbf{0 . 0 1 1}$ & 1,000 & 0.437 & 0.655 & $\mathbf{0 . 0 0 7}$ \\
\hline IV & 0.656 & 0.085 & 0.437 & 1,000 & 0.757 & 0.096 \\
\hline V & 0.450 & $\mathbf{0 . 0 4 5}$ & 0.655 & 0.757 & 1,000 & $\mathbf{0 . 0 4 7}$ \\
\hline
\end{tabular}

$\mathrm{p}$ values for pairs of seed lots between which there are significant differences are shown in bold type

interaction had significant effect on the variation of diameter $(\mathrm{p}<0.001)$ (Table 7).

Table 7. Results of Two-way ANOVA analysis of variance of the seed lot progenies stem diameter at the age 10 years

\begin{tabular}{|l|r|r|r|r|c|}
\hline \multicolumn{1}{|c|}{ Effect } & \multicolumn{1}{c|}{ SS } & \multicolumn{1}{c|}{ DF } & \multicolumn{1}{c|}{ MS } & \multicolumn{1}{c|}{ F } & p \\
\hline Intercept & 21900.73 & 1 & 21900.73 & 7494.745 & $<0.001$ \\
\hline Site & 4882.66 & 1 & 4882.66 & 1670.918 & $<0.001$ \\
\hline Seed lot & 86.50 & 5 & 17.30 & 5.920 & $<0.001$ \\
\hline Site / Seed lot & 87.18 & 5 & 17.44 & 5.967 & $<0.001$ \\
\hline Error & 1633.48 & 559 & 2.92 & & \\
\hline
\end{tabular}

The graph of mean stem diameters on both test sites, derived from ANOVA, indicates that the highest values have the progeny of seed lot III and V (Fig. 2).

As one can see, all five seed lot progenies exceed the diameter of control. As evidenced by the Fisher's LSD test, only two progenies selected mixtures (III and V) showed the presence of significant differences in DBH in pair wise comparison with control and other seed lot (Table 8). Progeny of clones with the highest seed yield (Fraction V) exceeds the control and two experimental seed lots (I and II) by DBH. Progeny of the fastest growing clones (fraction III) was significantly better than control and seed lot I. There were significant differences between the average $\mathrm{DBH}$ progenies of
Table 8. Results of pair wise comparisons of the average diameter of the seed lot progenies (LSD test)

\begin{tabular}{|c|c|c|c|c|c|c|}
\hline $\begin{array}{c}\text { Seed } \\
\text { lot }\end{array}$ & I & II & III & IV & V & $\begin{array}{c}\text { control } \\
\text { F-steppe }\end{array}$ \\
\hline I & 1.000 & 0.453 & $\mathbf{0 . 0 1 4}$ & 0,135 & $\mathbf{0 . 0 0 1}$ & 0.889 \\
\hline II & 0.453 & 1.000 & 0.088 & 0.446 & $\mathbf{0 . 0 0 9}$ & 0.286 \\
\hline III & $\mathbf{0 . 0 1 4}$ & 0.088 & 1.000 & 0.364 & 0.338 & $\mathbf{0 . 0 0 2}$ \\
\hline IV & 0.135 & 0.446 & 0.364 & 1.000 & 0.068 & 0.051 \\
\hline V & $\mathbf{0 . 0 0 1}$ & $\mathbf{0 . 0 0 9}$ & 0.338 & 0.068 & 1.000 & $\mathbf{0 . 0 0 0}$ \\
\hline
\end{tabular}

$\mathrm{p}$ values for pairs of seed lots between which there are significant differences are shown in bold type

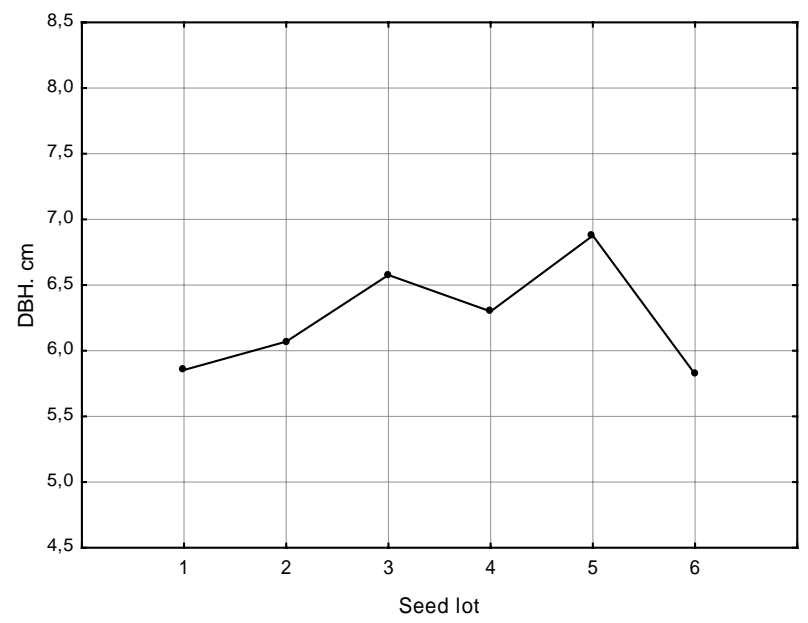

Figure 2. Mean diameter (DBH) of the seed lot progenies on both test sites at the age 10 years (6- control for Forest-Steppe)

seed lots II, III and control, as well as between the offspring of mixtures III and IV in the Forest Steppe zone.

The difference between test sites on DBH of seed lots progenies were also statistically significant as in the case of the average height. Progeny of high-yielding clones (V mixture) was the undisputed leader among other seed lots in growth at 26 years in Ukraine's Northern Steppe (Table 9).

Table 9. Survival, height $(\mathrm{H}, \mathrm{m})$, breast height diameter of stem $(\mathrm{DBH}, \mathrm{cm})$ and stem volume $\left(\mathrm{V}, \mathrm{m}^{3}\right)$ of 26 (in Forest-Steppe) years progenies of Pinus sylvestris seed lots

\begin{tabular}{|c|c|c|c|c|c|c|c|c|}
\hline \multirow{2}{*}{ Seed lot } & \multirow{2}{*}{ Site } & \multirow{2}{*}{$\begin{array}{c}\text { Survival, } \\
\%\end{array}$} & \multicolumn{2}{|c|}{ H } & \multicolumn{2}{|c|}{ DBH } & \multicolumn{2}{c|}{ V } \\
\cline { 5 - 9 } & & & $\overline{\mathrm{X}} \pm \mathrm{S}_{\overline{\mathbf{X}}}$ & $\mathbf{t}$ & $\overline{\mathrm{X}} \pm \mathrm{S}_{\overline{\mathbf{X}}}$ & $\mathbf{t}$ & \multirow{2}{*}{$\mathbf{m}^{\mathbf{3}}$} & $\begin{array}{c}\text { \% to } \\
\text { control }\end{array}$ \\
\hline I & $\mathrm{S}$ & 41 & $10.25 \pm 0.24$ & $4.05^{* * *}$ & $10.0 \pm 0.4$ & 0.2 & 0,042 & 120.0 \\
\hline II & $\mathrm{S}$ & 43 & $8.10 \pm 0.39$ & -0.47 & $7.8 \pm 0.5$ & $-2.75^{\star *}$ & 0,021 & 60.0 \\
\hline III & $\mathrm{S}$ & 34 & $10.06 \pm 0.39$ & $3.06^{* *}$ & $9.7 \pm 0.5$ & -0.2 & 0,039 & 111 \\
\hline IV & $\mathrm{S}$ & 40 & $9.36 \pm 0.43$ & 1.69 & $9.7 \pm 0.5$ & -0.2 & 0,037 & 106 \\
\hline V & $\mathrm{S}$ & 35 & $11.68 \pm 0.29$ & $6.75^{* * *}$ & $12.2 \pm 0.5$ & $3.23^{* *}$ & 0,069 & 197 \\
\hline Control & $\mathrm{S}$ & 35 & $8.36 \pm 0.40$ & - & $9.8 \pm 0.6$ & - & 0,035 & 100 \\
\hline
\end{tabular}

$\mathrm{t}$-value relative to control, the value at a significance level of ${ }^{\star} 0.05 ;{ }^{\star \star} 0.01 ;^{\star * \star} 0.001$ 
This progeny was significantly higher than control in height $(\mathrm{t}=6.75)$ and stem diameter $(\mathrm{t}=3.23)$.

The progeny of the seed lot II had the lowest growth characteristics at this age. This progeny had significantly less diameter trhan control $(t=-2.75)$. Progenies of mixture I and III differed significantly from local control in one growth characteristic - mean height $(t=4.05$ and 3.06).

In terms stem volume, 4 from 5 studied progenies had a volume greater than in local control Steppe by $6-97 \%$ at age 26 year. The volumes of the stem of these progenies differ slightly relative to the second control F-steppe at this age. Progeny of three high-yielding clones (fraction V) had the highest average volume of stem $\left(0.069 \mathrm{~m}^{3}\right)$ at 26 years of age in Northern Steppe and it was higher in relation to control. Only the progeny of seed lot II had $40 \%$ less stem volume than control.

Seed orchards are the principal delivery method for genetically selected materials to operational reforestation programs in many countries in the world (Stoehr et al., 2004; Jansson et al., 2016). Opportunities for enhancing the genetic quality of orchard seed lots are essential for the establishment of fast growing and sustainable tree plantations.

Progeny tests are usually aimed at analyzing progeny performance and inheritance of the traits of interest (Kroon et al., 2011; Gailis et al., 2020). The different reaction of the studied progenies to different environmental conditions is of great importance. Understanding the impact of $\mathrm{G} \times \mathrm{E}$, the role of environments in generating $\mathrm{G} \times \mathrm{E}$ and the problems and opportunities is vital to efficient breeding programme design and deployment of genetic material (Berlin et al., 2015; Li et al., 2017).

Our studied progenies showed special results regarding local control at different ages in different ecological conditions. The following trends were identified: in more or less favorable environmental conditions (less hot and humid Forest-Steppe climate and more fertile fresh sandy loam soil): significant improvement in the growth rates of progenies of seed orchards aged 3 to 10 years. The opposite process took place in less optimal climatic and soil conditions (hotter and drier Steppe climate with harsher winter and very poor sandy dry soils): 4 out of 5 progenies studied worsened their growth indicators relative to local control at the age of 3 to 26 years.

At the same time, there was a significant improvement in the growth of local control compared to control from more favorable environmental conditions. This indicates a more important role of adaptation of local genotypes to harsh environmental conditions, compared to their growth rate. Similar results were obtained when testing Scots pine in harsh areas such as northern Sweden (Calleja-Rodriguez et al., 2019). Data research support the hypothesis that tree height assessed in harsh conditions with low survival is likely to reflect health and ability to survive to a greater extent than growth rate.

Genotype-environment interaction $(\mathrm{G} \times \mathrm{E})$ had a critical impact on the design of a breeding programme and the resulting genetic gains for spruce (Picea abies (L.) H. KARST.) (Berlin et al., 2015). The $\mathrm{G} \times \mathrm{E}$ interaction was both statistically and practically significant when tested spruce families in five zones located in north-central interior British Columbia (Xie, 2003). Zhelev et al. (2003) and Hannrup et al. (2008) reported that estimates of genetic correlation between tree heights or diameters of Pinus sylvestris (L) at different test sites are moderate to high. Based on these publications, it follows that for these growth characteristics, the interaction between the genotype and the environment is negligible for this species. In a later publication Zhelev and Evtimov (2017) concluded that the two factors - family and block and their interaction had significant effect on the variation of diameter the half-sib families of Scots pine.

10 years of testing of the seed lot progenies in the Forest Steppe shows that the progenies of the three fastest growing clones is the best in terms of height, diameter and stem volume. It can be argued that the offspring of this seed lot (from three fastest growing clones in the same proportion) was also one of the best in the growth and productivity after 26 years of testing in the Steppe zone. That is, collecting seeds from the fastest growing clones on seed orchards can be an effective way to increase the growth rate of the created forest plantations. Such a decrease in the number of genotypes reduces the genetic variability of the created plantations. However, this decrease cannot be compared with clonal forestry (Ingvarsson \& Dahlberg, 2019).

The problem of the influence of the yield of cones and seeds of the Scots pine trees on the growth of their progenies is controversial and complex. It is generally accepted that clones of plus trees of pine vary widely in seed production (Matziris, 1993; Kroon et al., 2017). The results of a study of the pine (Pinus pinaster Aiton) conducted in Central Spain show that the phenotypic selection of trees with higher yields of cones did not affect the growth of their progeny (Bravo et al., 2017). Results of our investigation of the half-sib progeny growth of high-yielding clones were controversial. Progeny of three high-yielding clones was the best in height and increment at age 3 years, in $\mathrm{DBH}$ and volume of stem at age 12 years and in height, $\mathrm{DBH}$ and volume at 26 years of age in Ukraine's Northern Steppe. At the same time, the progeny of the second seed lot, which contains not only the seeds of all high-yielding clones, but also the seeds of clones with an average seed yield showed the lowest results in height, diameter, and stem volume at 12 and 26 years in the Northern Steppe. 


\section{Conclusion}

Many years of research of the progeny tests of plus trees of Scots pine in the Northern Steppe and Southern ForestSteppe of Ukraine indicate the economic efficiency of using genetically improved seeds, especially in more favorable climatic and soil conditions. It is also promising to assess the growth of clones on seed plantations for the selection and use of the fastest growing. Clones with the highest yields of cones and seeds should not be excluded from the tests, as their progenies may give special results in certain environmental conditions.

\section{References}

Anuchin N., 1982, Forest Industry, Moscow. (in Russian)

Berlin M., Jansson G. \& Högberg K., 2015, Genotype by environment interaction in the southern Swedish breeding population of Picea abies using new climatic indices. Scandinavian Journal of Forest Research 30(2): 112-121. doi/abs/10.1080/02827581.2014.978889

Bravo F., Maguire D. \& González-Martínez S., 2017, Factors affecting cone production in Pinus pinaster Ait.: lack of growth-reproduction trade-offs but significant effects of climate and tree and stand characteristics. Forest Systems 26(2): 1-12. https://doi.org/10.5424/fs/2017262-11200

Calleja-Rodriguez A., Andersson G., Wu H., Mullin T. \& Persson, T., 2019, Genotype - by - environment interactions and the dynamic relationship between tree vitality and height in northern Pinus sylvestris. Tree Genetics \& Genomes 15(36): 1-15. doi.org/10.1007/ s11295-019-1343-8

Chmura D.J., Rożkowski R. \& Chałupka W., 2012, Growth and phenology variation in progeny of Scots pine seed orchards and commercial seed stands. Eur J Forest Res. 131: 1229-1243. https://doi.org/10.1007/s10342 $-012-0594-9$

Danusevicius D. \& Lindgren D., 2004, Progeny Testing Preceded by Phenotypic Pre-selection - Timing Considerations. Silvae Genetica 53(1): 20-26.

Ingvarsson P.K. \& Dahlberg H., 2019, The effects of clonal forestry on genetic diversity in wild and domesticated stands of forest trees, Scandinavian Journal of Forest Research 34(5): 370-379. doi: 10.1080/ 02827581.2018.1469665

Ivković M., Gapare W., Yang H., Dutkowski G., Buxton P. \&Wu H., 2015, Pattern of genotype by environment interaction for radiata pine in southern Australia. Annals of Forest Science 72: 391-401. doi:10.1007/s13595-014-0437-6

Gailis A., Zeltiņš P., Purviņš A., Augustovs J., Vīndedzis V., Zariņa I. \& Jansons Ā., 2020, Genetic parameters of growth and quality traits in open-pollinated silver birch progeny tests. Silva Fennica 54(2): article id 10220.14 pp. https://doi.org/10.14214/sf.10220

Hannrup B., Jansson G. \& Danell Ö., 2008, Genotype by environment interactions in Pinus sylvestris L. in southern Sweden. Silvae Genetica 57(6): 306-311.

Hayda Y., Los S., Yatsyk R., Tereshchenko L., Shlonchak G., Mytrochenko V., Neyko I., Samodai V., Smashnyuk L., Klisz M. \& Mohytych V., 2019, Seed orchards in Ukraine: past, present and prospects. Folia Forestalia Polonica, Series A - Forestry 61(4): 284-298. doi: 10.2478/ ffp-2019-0028

Jansson G., Hansen J., Haapanen M., Kvaalen H. \& Steffenrem A., 2016, The genetic and economic gains from 14 forest tree breeding programmers in Scandinavia and Finland. Scandinavian Journal of Forest Research 32(4): 273-286. doi: 10.1080/02827581.2016.1242770

Kroon J., Ericsson T., Jansson G. \& Andersson B., 2011, Patterns of genetic parameters for height in field genetic tests of Picea abies and Pinus sylvestris in Sweden. Tree Genetics \& Genomes 7: 1099-1111. doi: 10.1007/ s11295-011-0398-y

Kroon J., Hallander J. \& Berlin M., 2007, Establishment of an elite Scots pine seed orchard in northern Sweden. Seed Orchard Conference, Umeå. http://www-genfys.slu.se/ staff/dagl/Umea07/Proceedings/00Proceedings.htm

Kroon J., Wennström U., Prescher F. Lindgren D. \& Mullin T., 2017, Estimation of clonal variation in seed cone production over time in a Scots pine (Pinus sylvestris L.) seed orchard. Silvae Genetica 58(1-6): 53-60. https://doi. org/10.1515/sg-2009-0007

Kurm M., Kiviste A., Kaur U. \& Maaten T., 2009, Growth Differences in the Progeny Trials of the Scots Pine (Pinus sylvestris L.). http://dx.doi.org/10.2478/ v10132-011-0070-1

Lai M., Dong L., Yi M., Sun S., Zhang Y., Fu L., Xu Z., Lei L., Leng C. \& Zhang L., 2017, Genetic Variation, Heritability and Genotype $\times$ Environment Interactions of Resin Yield, Growth Traits and Morphologic Traits for Pinus elliottii at Three Progeny Trials. Forests 8(11): 409-425. https://doi. org/10.3390/f8110409.

Lee S., 2002, Selection of parents for the Scots pine breeding population in Britain Forestry: An International Journal of Forest Research 75(3): 293-303. doi.org/10.1093/ forestry/75.3.293

Li Y., Suontama M., Burdon R. \& Dungey H., 2017. Genotype by environment interactions in forest tree breeding: review of methodology and perspectives on research and application. Tree Genetics \& Genomes 13(60). doi. org/10.1007/s11295-017-1144-x

Mazhula O.S. \& Voiytyuk V.P., 2000, Dynamics of productivity of Scots pine plantations. Scientific Bulletin of USLU. 10(4): 155-161. https://cyberleninka.ru/article/n/ 
dinamika-urozhaynosti-plantatsiy-sosni-zvichaynoyi/ viewer

Matziris D., 1993, Variation in cone production in a clonal seed orchard of black pine. Silvae Genetica 42: 136-140.

Pogrebnyak P.S., 1955, The bases of the forest typology. Second edition, Academy of Sciences of the Ukrainian SSR, Kiev, 452 pp. (in Russian)

Stoehr M., Webber J. \& Woods J., 2004, Protocol for rating seed orchard seedlots in British Columbia: quantifying genetic gain anddiversity. An International Journal of Forest Research 77(4): 297-303. https://doi.org/10.1093/ forestry/77.4.297
Xie C.-Y., 2003, Genotype by environment interaction and its implications for genetic improvement of interior spruce in British Columbia. Canadian Journal of Forest Research 33(9): 1635-1643. doi.org/10.1139/x03-082

Zhelev P., Ekberg I., Eriksson G. \& Norell L., 2003, Genotype environment interactions in four full-sib progeny trials of Pinus sylvestris (L.) with varying site indices. Forest Genetics 10(2): 93-102.

Zhelev P. \& Evtimov I., 2017, Diameter growthand survival of local half-sib families of scots pine (Pinus sylvestris L.) in Yundola, Bulgaria. Genetika 49(3): 819-829. 